\title{
Management and remediation of contaminated sites at Casey Station, Antarctica
}

\author{
Ian Snape, Martin J. Riddle, and Jonathan S. Stark
}

Human Impacts Research, Australian Antarctic Division, Channel Highway, Kingston, Tasmania 7050, Australia

Coleen M. Cole

Department of Primary Industries, Water and Environment, GPO Box 44A, Hobart, Tasmania 7001, Australia

Catherine K. King

CSIRO Energy Technology, Lucas Heights Science and Technology Centre, New Illawarra Road, Lucas Heights, NSW 2234, Australia

\section{Sabine Duquesne}

National Research Centre for Environmental Toxicology, University of Queensland, Queensland, Australia

\section{Damian B. Gore}

Department of Physical Geography, Macquarie University, Sydney, NSW 2109, Australia

Received August 2000

ABSTRACT. The Protocol on Environmental Protection to the Antarctic Treaty requires that past and present work sites be cleaned up unless removal would result in greater adverse environmental impact than leaving the contaminant in its existing location. In the early 1990s Australia began the documentation of contaminated sites associated with its research stations, which resulted in an extensive record of contamination at abandoned stations and waste-disposal sites. Currently the technical capability to remediate these sites does not exist because of environmental challenges that are unique to the cold regions. Investigations indicate that clean-up operations in the past have proceeded without adequate precautions and without effective monitoring. To address these problems, three research priorities have been identified to assist meeting international and national obligations to clean up these sites. They are: understanding contaminant mobilisation processes; development of ecological risk assessment for use in monitoring and setting priorities; and development of clean-up and remediation procedures. This study provides sufficient information to guide the completion of a clean-up at Casey Station and to indicate how other similar sites should be managed. The next stage is to develop the theory into an operational plan to include detailed protocols for clean-up, monitoring, site remediation, and management of the waste stream from site to final repository. To achieve this, the Australian Antarctic Division has established a contaminated sites taskforce to facilitate the transition from research and development of techniques to implementation of suitable clean-up options.

\begin{tabular}{lc}
\multicolumn{1}{c}{ Contents } & 199 \\
Introduction & 200 \\
Background & \\
Recommendations from preliminary & 201 \\
$\quad$ assessment & \\
Investigations, findings, and management & 203 \\
$\quad$ implications \\
$\begin{array}{l}\text { Mobilisation, dispersion, and accumulation } \\
\text { processes }\end{array}$ \\
$\begin{array}{l}\text { Identification and monitoring of biological } \\
\text { impacts }\end{array}$ \\
$\begin{array}{l}\text { Summary and recommendations } \\
\text { Conclusions }\end{array}$ \\
$\begin{array}{l}\text { Acknowledgements } \\
\text { References }\end{array}$ \\
$\begin{array}{l}\text { Introduction } \\
\text { In many temperate and some Arctic polar regions there are }\end{array}$ \\
reasonably well-established guidelines and protocols for \\
the assessment and subsequent management of contam- \\
inated sites, and generally the compulsion to clean up
\end{tabular}

contaminated sites is driven by legislature or litigation. This is not the case for Antarctica, where there are no universally accepted guidelines and there is no binding process for assigning liability for environmental damage. However the Protocol on Environmental Protection to the Antarctic Treaty, commonly known as the Madrid Protocol (ATCPs 1993), which was ratified in 1998, does commit Antarctic Treaty Parties to the comprehensive protection of the Antarctic environment and dependent and associated ecosystems, and designates Antarctica as a natural reserve devoted to peace and science. Annex III to the Protocol (Waste Disposal and Management) established that past and present work sites shall be cleaned up unless they are designated as a historic site or monument, or removal by any practical option would result in greater adverse environmental impact than leaving it in its existing location or condition.

The Environmental Protocol is part of a process of increasing environmental awareness that has seen many changes in Antarctic operations during the last 20 years. 


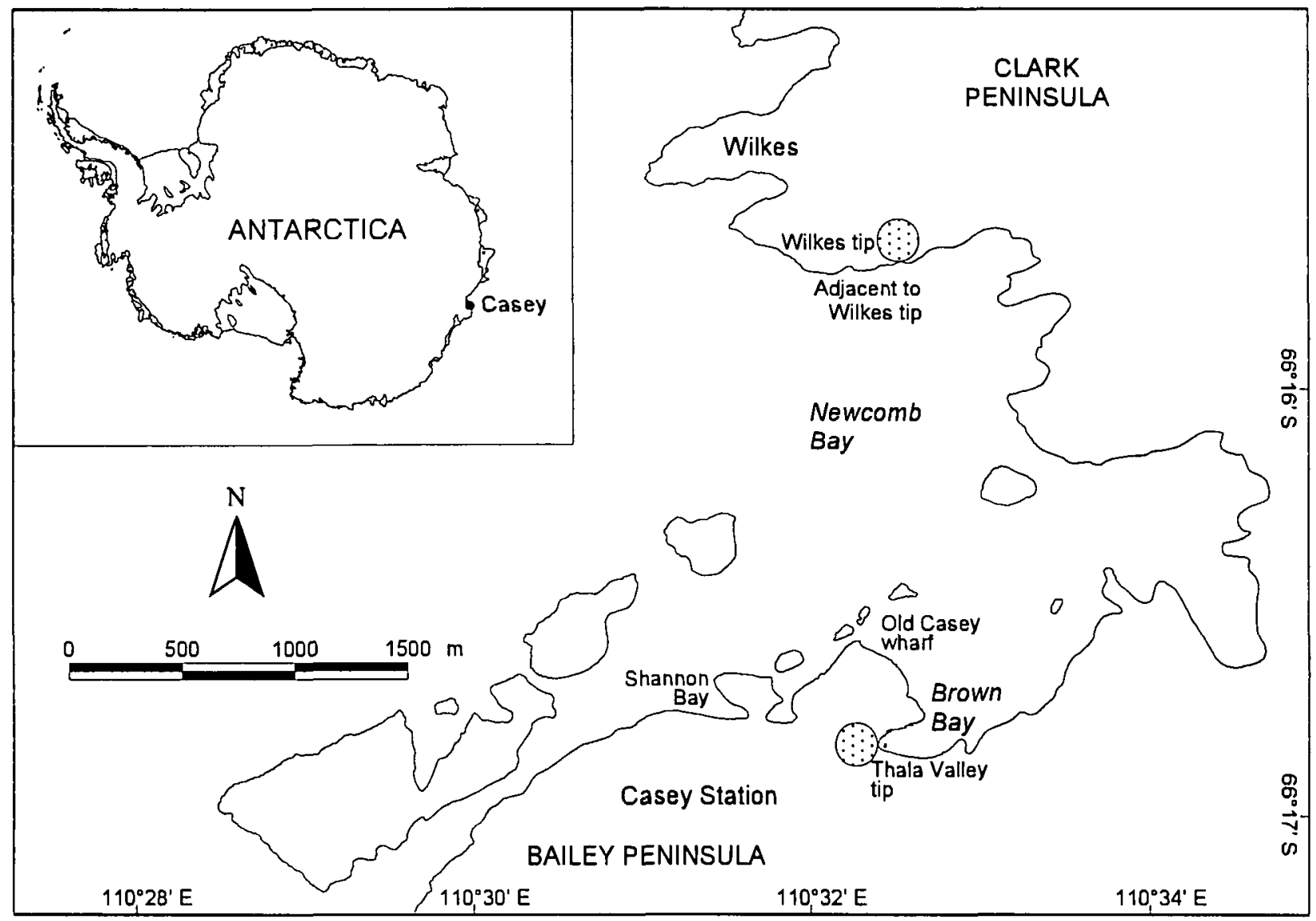

Fig. 1. Regional map of Antarctica, the Windmill Islands, and Casey and Wilkes stations. The locations of impacted sites described in the text are: Thala Valley tip (TVT), Wilkes tip (WT), Brown Bay, Shannon Bay (SB), Old Casey wharf (OCW), and adjacent to Wilkes tip (AWT).

Waste-management practices such as disposal to tips, seaicing (dumping waste onto sea ice until it melts or drifts away), and open burning are no longer commonly practiced in Antarctica. However, there is a considerable legacy of waste from past activities, which includes abandoned stations, waste-disposal sites, and chemically contaminated sediments. Based on extrapolation from a few welldocumented sites, we estimate that the volume of abandoned, unconfined tip materials in Antarctica is somewhere between 1 and 10 million $\mathrm{m}^{3}$, and that the volume of petroleum-contaminated sediment is similar (Reed and Sletten 1989; Sheppard and others 1994, 2000; Acero and others 1996; Agraz and others 1998; Snape and others 1998; Deprez and others 1999). In relation to the area of Antarctica, these volumes are very small, but when placed in the context of their habitat - largely on ice-free rocky coastal oases that constitute less than $0.01 \%$ of the continent, this is a sizable amount indeed. Moreover, these relatively rare areas are essential breeding grounds for animals that are themselves important components in Southern Ocean ecosystems (Pickard 1986). The impact that might be occurring in these areas is therefore disproportionate to their areal extent.

At present it is too early to tell how different countries will respond to Annex III of the Protocol, or if they are financially or technically capable of responding in a way that would satisfy the condition that clean-up should not lead to greater adverse environmental impacts. Australia's response in the early 1990 s was to begin a program of contaminated sites identification and assessment at the main Australian Antarctic stations of Casey, Mawson, and Davis, and on sub-Antarctic Macquarie Island, as well as at smaller field bases, such as Law Base in the Larsemann Hills and the abandoned base at Heard Island. The work reported here builds on the preliminary identification and assessment of contaminated sites in the region of Casey Station, East Antarctica (Deprez and others 1994, 1999). Our objective is to develop an approach to the remediation of abandoned work sites and waste-disposal sites that satisfies the requirements of the Protocol and that could be applied to contaminated sites throughout Antarctica.

\section{Background}

Casey Station and its two predecessors, Wilkes and Old Casey, are located in the Windmill Islands, East Antarctica, at $66^{\circ} 17^{\prime} \mathrm{S}, 110^{\circ} 32^{\prime} \mathrm{E}$ (Fig. 1). The original station, Wilkes, is located on Clark Peninsula and was built by the United States in 1957-58 in support of the International Geophysical Year (IGY). In February 1959, at the end of the IGY, Wilkes Station was handed over to Australia. Wilkes proved to be poorly situated, and rapid snow accumulation hindered operations. This prompted the 
Australians to construct a new station, Casey, on Bailey Peninsula. In 1969 Wilkes was abandoned and all equipment, fuel, buildings, and waste were left on Clark Peninsula. The Australians moved into what was then called 'Repstat' (Replacement Station) and is now referred to as 'Old' Casey Station. Old Casey Station consisted of several buildings, including a long elevated tunnel structure set across the prevailing wind in the shape of a wing to prevent snow accumulation. The station was operational between 1969 and 1989, when it was replaced by the current Casey Station, which is also located on Bailey Peninsula about $500 \mathrm{~m}$ southwest of the old station.

Both Old and New Casey stations are located on coastal ice-free rock and gravel promontories or peninsulas. Sea ice is usually present in the winter months, but melts or is blown out to sea each summer. Average wind speed at Casey is $18 \mathrm{~km} \mathrm{~h}^{-1}$ in summer and $31 \mathrm{~km} \mathrm{~h}^{-1}$ in winter. Mean summer temperatures are about $3^{\circ} \mathrm{C}$ and mean winter temperatures are about $-20^{\circ} \mathrm{C}$ (Deprez and others 1994, 1999). Soil development is generally poor in the immediate vicinity of Casey Station, with glacial, fluvial, and marine deposits being better described as mineral sediments. However, mosses and lichens in the Windmill Islands are amongst the most diverse and abundant in continental Antarctica (Smith 1986). Nearby are breeding grounds for seals, penguins, and flying birds, and shallow near-shore marine areas support a diverse community of algae, invertebrates, and fish.

Twenty sites at the Old and New Casey stations were identified as known to be either contaminated or potentially contaminated on the basis of previous studies, written records, and interviews with past expeditioners (Deprez and others 1994, 1999). Two sites near Old Casey (the waste-disposal site known as Thala Valley tip and the site of the old mechanical workshop and powerhouse) were likely to be most contaminated because of the type of activity carried out and were investigated to determine the nature and extent of chemical contamination. A gridbased geochemical survey of Thala Valley found that sediments had concentrations of contaminants, including heavy metals (copper, lead, and zinc), polycyclic aromatic hydrocarbons, and petroleum hydrocarbons, that were significantly above background levels (Deprez and others 1994, 1999). Contaminant concentrations for these chemicals exceeded levels at which further investigation is warranted according to Australian and New Zealand Environment and Conservation Council and National Health and Medical Research Council environmental investigation guidelines (ANZECC/NH\&MRC 1992). High concentrations of cadmium, copper, lead, and zinc were also reported in sea water and a shellfish taken from Brown Bay adjacent to the Thala Valley tip (Deprez and others 1994, 1999). Several fuel spills are known to have occurred in the vicinity of the workshop and powerhouse, and total petroleum hydrocarbon (TPH) concentrations near the workshop buildings were the highest for the Casey region $\left(47,600 \mathrm{mg} \mathrm{kg}^{-1}\right)$.

\section{Recommendations from preliminary assessment}

The identification and assessment of contaminated sites at Casey concluded with a series of eight broad recommendations for future management (Deprez and others 1994, 1999). These recommendations focused primarily on the urgent need to clean up Thala Valley tip, and for further investigations before the practical options for removal could be selected and implemented. In 199596 a clean-up operation to remove the tip in Thala Valley was undertaken, and an assessment of the effectiveness, or otherwise, of the operation is now possible. Similarly, investigation of other sites has continued, further highpriority sites have been identified, and clean-up and siterehabilitation options can now be considered. This paper reports progress on the recommendations made by Depre $z$ and others $(1994,1999)$ and the development of clean-up and site remediation options in the hope that this research will have general applicability to other contaminated sites in Antarctica.

1. The Casey Contaminated Sites Register should be maintained, and upgraded as further sampling, remedial efforts, and any future incidents eventuate (Deprez and others 1994, 1999).

The register of contaminated sites has been upgraded to a data-management system based on a proprietary geographic information system (ArcView GIS). This system has the advantage of providing a flexible means for collating, displaying, and analysing site-specific information on contamination, together with background information such as topography, catchments and drainage basins, buildings, roads, and other station infrastructure. The distance to Antarctica has indirectly created a problem with managing the information on contaminated sites in the past. The problem is one of continuity and arises because field personnel are often employed on short-term contracts for only one summer season. Thus, a centralised data-management system that can be accessed simultaneously by all users is required to track the various stages of contaminated sites management, from initial assessment through to eventual rehabilitation and validation. To achieve these objectives, a web-linked GIS has been designed to provide a single definitive record of activities at the sites (www.aad.gov.au). This includes all information in the original contaminated sites register, but also accommodates information on site characteristics (for example, nature and quantity of waste, condition of containers, and concentrations before clean-up), details of sampling (for example, date, methods, and person sampling), and management actions (for example, recommendations on removal techniques, risks to human health, monitoring requirements, and current status of the sites) (Babicka and others 2000).

2. Removal of rubbish mixed with soil at the end of Thala Valley should be undertaken in such a manner as to prevent any further release of contaminants (Deprez and others 1994, 1999).

For a period of two months in the summer of 1995-96 
large items of rubbish were extracted from the Thala Valley tip using a log grab attached to a Cat 240 E excavator. Approximately $300 \mathrm{~m}^{3}(149,200 \mathrm{~kg})$ of large rubbish material and associated soil was removed from the tip and transferred to half-height open ' $\mathrm{C}$ ' shipping containers before being returned to Australia and consigned to a landfill in Tasmania. The remaining small fragments of rubbish and fine loose sediment in Thala Valley were pushed into a stockpile until further management action could be decided. The process of rubbish removal from Thala Valley and subsequent storage and transport were not monitored to determine whether there was further release of contaminants (discussed in detail below).

3. Once rubbish mixed with soil at the bottom end of Thala Valley is removed, re-sampling of the rubbish site should be performed to verify whether removal was successful and that contaminants in the leachates are within acceptable environmental levels (Deprez and others 1994, 1999).

After the large rubbish was removed it became apparent that the quantity of contaminated soil remaining far exceeded the available capacity to store and transport it. It was also obvious that the disturbance caused by partial removal of the tip had created the potential for mobilisation and dispersion of freshly exposed contaminated soils by melt water and by sea-water inundation during extreme high tides.

4. Research be undertaken to investigate whether there are any impacts on Brown Bay and its ecosystem as a result of the migration of anthropogenic contaminants (Deprez and others 1994, 1999).

Each summer, as the snow melts, water flows through the remains of the disturbed Thala Valley waste-disposal site. It is therefore likely that contaminants are being carried into Brown Bay and that the marine ecosystem is at risk. Contaminant dispersal and accumulation can be confirmed by sampling water and sediments in Brown Bay; however, to fully understand the environmental impacts it is necessary to establish the link between contaminant levels and biological effects. The most rigorous sampling design for determining whether contamination causes a change to a biological community will include both temporal (before and after) and spatial (potentially impacted and non-impacted sites) controls to separate the effects of natural variability from effects attributable to the contaminants. Unfortunately, ecological information is not available for Brown Bay prior to when the tip was established in Thala Valley or before the removal of large items in 1996. Therefore the nature of impacts on the biota of Brown Bay can only be inferred by comparisons with other locations that are situated away from sources of contaminants. The inference can be supported with additional independent information; for example, dose-response toxicity tests would indicate whether or not concentrations measured in the environment are above threshold levels that are likely to cause adverse effects to the biota. It is not known whether Antarctic organisms respond to contaminants at levels comparable to those that cause effects in temperate species, because very few toxicity tests have been undertaken using Antarctic species.

5. Further investigation be carried out in more detail for the site at the large fuel spill (Site 3), both the upper and lower fuel-siorage areas (Sites 4 and 18), and the area around the incinerator (Site 16) (Deprez and others 1994, 1999).

All the potentially contaminated fuel-spill sites (including sites $3,4,16$, and 18) warrant detailed investigations. However, simply measuring the levels of contaminants will not provide sufficient information to determine the best management practice at these sites. The characteristics of various physical, chemical, and biological processes that affect contaminants in soils need to be better understood for Antarctic conditions before clean-up and remediation can commence.

6. Sampling of background conditions be conducted to enable a more comprehensive determination of baseline levels, which would provide a reference for future management options such as remediation or removal of contaminants (Deprez and others 1994, 1999).

Defining background levels, or a baseline, is essential for understanding the significance of concentrations measured at contaminated sites, for indicating the concentrations that might be of ecological concern, and for setting targets for remediation. However, monitoring techniques that are suitable for application in Antarctica are not yet fully developed, and, for a continent such as Antarctica, which is under multinational jurisdiction, it is essential that baseline information is collected in such a way that it is comparable among different research groups. The importance of standardising Antarctic monitoring is recognised by the Council of Managers of National Antarctic Programs (COMNAP), who commissioned a comprehensive methods paper, Standard techniques for monitoring in Antarctica (COMNAP 2000). Many of the standard methods in this manual are suitable for determination of baseline levels in areas such as the Windmill Islands. However, measurements of some important environmental baseline parameters in Antarctica require specialised procedures. For example, some elements of common environmental concern, such as lead, are only present at very low (parts per trillion) levels in samples from uncontaminated areas, including pristine Antarctic snowmelt and clean groundwater. To measure such heavy-metal contaminants at trace levels requires ultra-clean laboratory facilities (Class-100 clean room) and extremely careful sampling procedures (for example, Gasparon 1998).

7. Monitoring of natural remediation and migration of contaminants in the mechanical workshop/powerhouse be undertaken, including the conduct of bioremediation studies on hydrocarbon-contaminated soils (Deprez and others 1994, 1999).

If transfer rates are slow and natural attenuation is fast, 
it may be that active management of the sites is not required or that it may create more environmental problems than leaving them undisturbed. However, if the reverse is true, where contaminants disperse rapidly into environmentally sensitive areas and breakdown occurs only slowly, then practical management schemes need to be developed as a priority. Technological and logistical problems associated with excavation and removal, and the environmental problems that could result, indicate that in situ treatment of petroleum contaminants is probably the only viable management strategy (Snape and others 2000). However, optimisation for local conditions will be necessary before in situ remediation techniques designed for temperate regions can be applied in the Antarctic. Environmental factors, including low temperatures and low concentrations of nutrients and available water, need to be overcome if microbial breakdown of contaminants through landfarming, biopiles, or air-sparging treatments is to be used effectively (see Reynolds and others 1997).

8. Options for arresting surface migration of hydrocarbons be further investigated for the original lower tank farm and the mechanical workshop/ powerhouse house (Deprez and others 1994, 1999).

The recommendation to use barriers or a bunding to prevent migration of contaminants is a good idea; however, they are difficult to implement in Antarctica. The main problem at Casey, and indeed most contaminated sites near Antarctic stations (for example, Marambio Station; Agraz and others 1998), is that they are often located in areas of snow accumulation and high water flow. This means that impermeable barriers may cause ponding and in areas of particularly high water flow, such as Thala Valley, they could not contain all the water from the seasonal melt. To overcome this problem, permeable barriers that selectively retain contaminants are currently being tested (Morris and others 2000; Snape and others, in press).

\section{Investigations, findings, and management implications}

Many of the recommendations made by Deprez and others (1994, 1999) in their preliminary identification and assessment of contaminated sites at Casey are being addressed by research being undertaken by the Australian Antarctic Division. Although the recommendations arose because of the problems at Casey, they have more general application. Hence, rather than deal with them in a sitespecific manner, research has been initiated to develop a generic approach to remediation in Antarctica. Using the contaminated sites at Casey Station as a case study, we hope to develop methodologies that will assist Australia to comply with the terms of Annex III of the Madrid Protocol at all its contaminated sites.

Three research priorities have been identified:

1. to understand mobilisation and dispersal processes so that procedures to reduce transport of contaminants can be included in clean-up operations;

2. to understand the impact of contaminants on local biological communities so that decisionmaking can proceed based on ecological assessment of risks, and so that monitoring procedures can be developed to ensure that the clean-up process does not cause greater environmental impacts; and

3. to develop clean-up and remediation procedures, so that wastes that can only be managed by removal are removed without causing adverse environmental impacts; and that those wastes that cannot be sensibly removed can be treated in situ.

Mobilisation, dispersion, and accumulation processes Petroleum spills

The site most seriously contaminated with hydrocarbons is the catchment of the workshop and powerhouse at Old Casey (Deprez and others 1994, 1999; Guille and others 1997). In the most contaminated parts of the catchment, hydrocarbons are dominated by $n$-alkanes in the range $\mathrm{C}_{12}-\mathrm{C}_{15}$, indicating largely undegraded light diesel fuel, and there are also patches of heavy aliphatics $\left(>n-C_{20}\right)$, indicating mineral lubricants. Guille and others (1997) used a Geographical Information System (GIS) to analyse the relationships between hydrocarbons and environmental parameters, such as drainage patterns, soil moisture, temperature, snow cover, and slope aspect. They concluded that the variability of hydrocarbons could in part be explained by environmental factors, and that biodegradation does occur in the contaminated sediments at Casey, although rates are much slower than in temperate regions. They also concluded that surface runoff dispersal of fine dust particles with hydrocarbons adsorbed to them is the main mechanism for transporting hydrocarbons. Movement of groundwater has been suggested as an alternative dispersion mechanism (Snape and others, in press; Cole and others 2000), because the lowest concentrations and most degraded hydrocarbons are in an area in the middle of the catchment that is only occasionally subjected to surface runoff. For most of the summer melt season, water percolates through the porous sediment in the upper catchment, dissolves and entrains adsorbed petroleum contaminants, and transfers them by ephemeral surface flow at a spring line above the lower part of the catchment. The transient nature of the surface runoff ensures that contaminants have time to degrade and evaporate in the middle of the catchment.

Regardless of the dispersal mechanism, hydrocarbons have been traced from the source near the workshop, through the catchment, and into Newcomb Bay (Guille and others 1997; Cole and others 2000; Snape and others, in press). This indicates that the rate of transfer to environmentally sensitive areas is faster than the rate of natural attenuation in the catchment. Petroleum contamination of the marine environment in other parts of the world is known to cause adverse effects to biota, and it is likely to do so here, as well.

Heavy metals from Thala Valley tip

The observation of solid hazardous waste in Thala Valley 
Table 1. Heavy-metal concentrations (mean and standard deviation), in Thala Valley tip compared with controls. Results are for a composite of six samples, each analyzed four times using distilled de-ionized water $(\mathrm{MQ}+), 1 \mathrm{M} \mathrm{HCl}, 1 \mathrm{M} \mathrm{HNO}_{3}$ and aqua regia. The most heavily contaminated values are for acid-extractable copper, lead, and zinc, although all metals reported here are higher than controls. All concentrations are in $\mathrm{mg} \mathrm{kg}^{-1}$.

\begin{tabular}{|c|c|c|c|c|c|c|c|c|}
\hline & \multicolumn{4}{|c|}{$\mathrm{MQ}+$} & \multicolumn{4}{|c|}{$\mathrm{HCl}$} \\
\hline Sample & \multicolumn{2}{|c|}{ Control } & \multicolumn{2}{|c|}{ Tip } & \multicolumn{2}{|c|}{ Control } & \multicolumn{2}{|c|}{ Tip } \\
\hline & Mean & SD & Mean & SD & Mean & $S D$ & Mean & SD \\
\hline $\mathrm{Ag}$ & 0.02 & $(0.00)$ & 0.02 & $(0.01)$ & 0.25 & $(0.01)$ & 3.25 & $(0.50)$ \\
\hline As & 0.04 & $(0.00)$ & 0.24 & $(0.03)$ & 0.66 & $(0.10)$ & 1.73 & $(0.12)$ \\
\hline $\mathrm{Cd}$ & 0.02 & $(0.00)$ & 0.10 & $(0.01)$ & 0.24 & $(0.02)$ & 17.69 & (1.65) \\
\hline $\mathrm{Cr}$ & 0.02 & $(0.00)$ & 0.01 & $(0.00)$ & 3.41 & $(0.26)$ & 21.83 & $(5.04)$ \\
\hline $\mathrm{Cu}$ & 0.18 & $(0.01)$ & 1.67 & $(0.33)$ & 10.29 & $(0.56)$ & 1458.93 & $(230.20)$ \\
\hline $\mathrm{Fe}$ & 5.83 & (1.88) & 1.07 & $(2.08)$ & 5147.45 & (278.88) & 23300.97 & $(6615.54)$ \\
\hline $\mathrm{Hg}$ & 0.02 & $(0.00)$ & 0.01 & $(0.00)$ & 0.02 & $(0.00)$ & 0.01 & $(0.00)$ \\
\hline $\mathrm{Mn}$ & 0.13 & $(0.01)$ & 3.72 & $(0.55)$ & 39.46 & (3.43) & 671.75 & (115.02) \\
\hline $\mathrm{Ni}$ & 0.57 & $(0.03)$ & 0.31 & $(0.01)$ & 10.38 & $(0.43)$ & 38.84 & $(8.49$ \\
\hline $\mathrm{Pb}$ & 0.02 & $(0.00)$ & 0.14 & $(0.01)$ & 6.52 & $(0.69)$ & 4880.64 & (944.64) \\
\hline $\mathrm{Sb}$ & 0.02 & $(0.00)$ & 0.11 & $(0.01)$ & 0.02 & $(0.00)$ & 12.49 & $(0.95$ \\
\hline $\mathrm{Sn}$ & 0.02 & $(0.00)$ & 0.01 & $(0.00)$ & 0.29 & $(0.25)$ & 46.18 & $(10.59)$ \\
\hline \multirow[t]{2}{*}{$\mathrm{Zn}$} & 0.33 & $(0.13)$ & 1.70 & $(0.37)$ & 25.65 & (3.13) & 3148.84 & $(453.80)$ \\
\hline & \multicolumn{4}{|c|}{$\mathrm{HNO}_{3}$} & \multicolumn{4}{|c|}{ Aqua regia } \\
\hline $\mathrm{Ag}$ & 0.18 & $(0.04)$ & 0.77 & $(0.15)$ & 0.02 & $(0.00)$ & 14.49 & $(1.08)$ \\
\hline As & 0.57 & $(0.07)$ & 2.09 & $(0.32)$ & 0.96 & $(0.07)$ & 11.99 & $(0.82)$ \\
\hline $\mathrm{Cd}$ & 0.25 & $(0.02)$ & 20.21 & (2.99) & 0.20 & $(0.02)$ & 24.49 & (1.08) \\
\hline $\mathrm{Cr}$ & 5.92 & (1.54) & 28.88 & (3.59) & 30.59 & $(4.13)$ & 59.97 & $(9.15)$ \\
\hline $\mathrm{Cu}$ & 15.87 & (2.71) & 1538.25 & $(127.59)$ & 32.83 & $(2.07)$ & 2198.79 & (91.74) \\
\hline $\mathrm{Fe}$ & 7721.11 & $(1714.82)$ & 27720.00 & $(2162.08)$ & 28589.09 & $(2951.13)$ & 111064.00 & $(4091.66)$ \\
\hline $\mathrm{Hg}$ & 0.02 & $(0.00)$ & 0.12 & $(0.04)$ & 0.03 & $(0.01)$ & 2.85 & $(0.38$ \\
\hline $\mathrm{Mn}$ & 83.22 & $(22.47)$ & 735.00 & $(74.74)$ & 347.07 & (46.76) & 1211.84 & (63.38) \\
\hline $\mathrm{Ni}$ & 12.18 & $(0.44)$ & 42.00 & $(6.18)$ & 37.58 & $(9.21)$ & 93.70 & $(8.57)$ \\
\hline $\mathrm{Pb}$ & 8.32 & $(2.93)$ & 6090.00 & $(747.40)$ & 7.49 & (1.07) & 6746.28 & (290.39) \\
\hline $\mathrm{Sb}$ & 0.19 & $(0.18)$ & 18.90 & (1.57) & 0.08 & $(0.03)$ & 61.22 & $(4.80)$ \\
\hline $\mathrm{Sn}$ & 0.40 & $(0.31)$ & 30.98 & (6.03) & 2.13 & $(0.53)$ & 319.82 & (8.29) \\
\hline $\mathrm{Zn}$ & 39.21 & $(10.46)$ & 3412.50 & $(315.00)$ & 73.65 & (4.83) & 4584.97 & (189.97) \\
\hline
\end{tabular}

tip indicates the location and type of contaminants that might be expected, but it does not prove that contaminants are mobile. To determine whether contaminants can be mobilised from rubbish or sediments in the waste-disposal site, samples were extracted using distilled de-ionised water as an analogue of the dissolution process that might occur naturally during the brief summer melt at Casey. Distilled de-ionised water was used as an analogue of Antarctic melt waters that are usually weakly carbonic and have very low dissolved cation, anion, or organic ligand concentrations. Weak acids (for example, acetic acid, $1 \mathrm{M}$ hydrochloric, or IM nitric acid) were used to simulate long-term dissolution of metals from the tip (Snape and coworkers, unpublished data). The analyses indicate that heavy metals that were present as contaminants in Thala Valley before the 1995-96 clean-up operation (Deprez and others 1994, 1999) still significantly exceed background values and ANZECC environmental investigation guidelines (Table 1). Acid-extractable metal concentrations are typically 100 to 1000 times greater in the wastedisposal site than at control locations. Consistently high concentrations in all replicates indicate that these high values are not artefacts or 'nuggets' of contamination, but represent the average composition of the medium- to finegrained sediment fraction.

Water and acid extractions estimate only the dissolved component that might be removed, and do not indicate what might be entrained or transferred through sorption to particles. To assess these processes, water was collected as it moved through the waste-disposal site and was analysed for dissolved and particulate contaminants. To isolate the contribution of the tip on water chemistry from other contaminated sites and station activity, runoff was divided into discrete stages within the Thala Valley catchment (Fig. 2). Using this approach, it is apparent that waters became highly contaminated with heavy metals as they flowed through the tip, and that the primary transfer mechanism is particle entrainment or sorption to particles (Table 2; Snape and others, in press). Of key importance, levels of heavy metals in marine waters from Brown Bay (Table 2) are significantly above background values. Metal concentrations are also sometimes above values prescribed in the ANZECC guidelines for the protection of marine aquatic ecosystems of high conservation or ecological value (ANZECC 1992: 1-7 and table 2.1; ANZECC and ARMCANZ 2000). Analysis of dissolved and particulate 


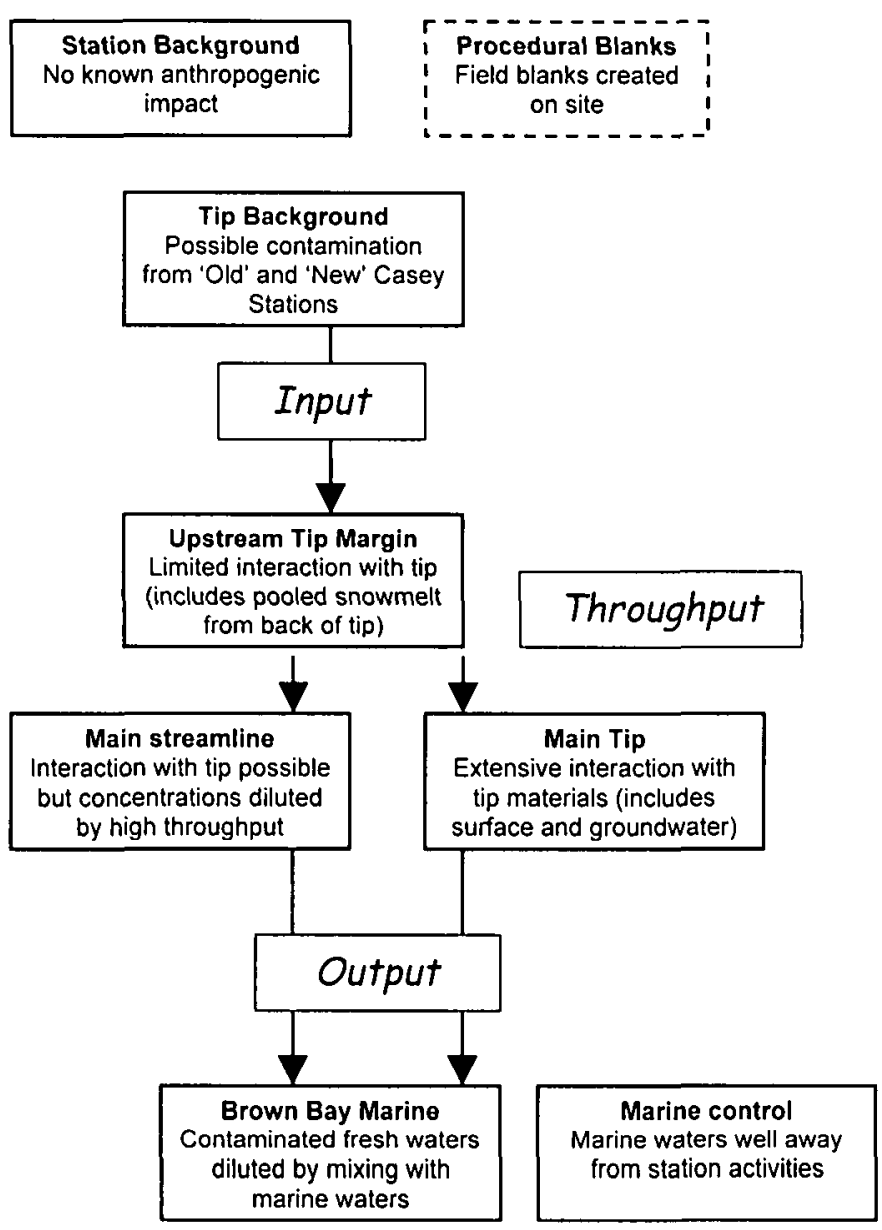

Fig. 2. Stages of water interaction with Thala Valley tip. Procedural blanks $(n=6)$ were analysed as a quality control measure. Station background samples $(n=6)$ were taken away from the direct impact of the stations to provide regional background levels for potential contaminant elements. Tip background samples $(n=8)$ were collected from the head of Thala Valley to isolate directly the effects of the tip on water quality. Samples from within the lower Thala Valley catchment are subdivided into three components: upstream tip-margin $(n=8)$; main streamline $(n=3)$; and main tip $(n=13)$ according to degree of water-tip interaction. Heavy-metal concentrations in marine controls $(n=$ 10) were less than the sensitivity of technique used for this pilot study, although heavy metals in Brown Bay $(n=21)$ were sometimes detectable at the $\mu \mathrm{g}^{1^{-1}}$ level.

phases indicates that contaminant adsorption to particles is important in the marine environment as well as on land. Although considerable work remains to define the flux between dissolved and particulate contaminants in fresh water and when runoff mixes with marine waters, unpublished observations from sediment traps implicate biofilms as the main type of contaminated marine particulates. This would explain some of the elevated metal levels in the tissues of certain filter-feeding marine invertebrates (discussed below).

The main conclusion regarding mobilisation and dispersal of metals from the Thala Valley tip is that although heavy-metal concentrations discharged into Brown Bay become diluted compared with groundwater and surface waters in the tip (Table 2), dilution is not rapid enough to prevent contaminant levels greatly exceeding background levels in waters in the bay. The measured concentrations of contaminants in Brown Bay shown in Table 2 should be regarded as low estimates, and considerably higher concentrations are predicted for periods when the front of the tip is inundated with marine water as a result of tidal fluctuation. As contamination is mostly associated with particulates it is likely that advection- and diffusion-controlled movement of contaminated particulates will dominate dispersal processes in the near-shore marine environment. Therefore contamination should be greatest where contaminated particulates accumulate. To test this, marine sediments and filter-feeding marine invertebrates from locations near to the waste-disposal site, and from control locations, were analysed for contaminants.

In a pilot study, sediments were analysed using instrumental neutron activation analysis to measure total concentrations for a wide variety of elements, and by inductively coupled plasma-atomic emission spectrometry, after partial extraction in $1 \mathrm{M} \mathrm{HNO}_{3}$ for 24 hours, to measure selected 'readily available' metals. Such partial extractions are commonly thought to provide an approximation of the concentrations of biologically available metals (for example, Batley and Maher, in press; Stark 1998; Morrisey and others 1994). Some sediments were also analysed for organic contaminants, including fuels, oils, solvents, and polychlorinated biphenyls using gas chromatograph and gas chromatograph mass spectrometry techniques (methods described in Guille and others 1997).

Levels of copper, lead, and antimony are obviously elevated in Brown Bay relative to nonimpacted control areas (Table 3, Fig. 3). Zinc, silver, and iron may also be elevated in some samples, although naturally occurring background values are not sufficiently well described to be able to draw conclusions with any confidence from the preliminary data presented here. Fuel and mineral lubricating oil were also present in sediments from Brown Bay in concentrations in the range 41-200 $\mathrm{mg} \mathrm{TPH} \mathrm{kg-1}$. Polycyclic aromatic hydrocarbons were found in one sample (0.8 $\mathrm{mg} \mathrm{kg}^{-1}$ ), although polychlorinated biphenyls were not detected in this pilot study. All control sites were free of petroleum contamination (Snape and others, unpublished data).

\section{Conclusions and predictions}

The conclusion from these preliminary geochemical observations is that heavy-metal contaminants known to be highly toxic when present at elevated levels in aquatic ecosystems are present in Brown Bay. The heavy metals and the organic compounds found in Brown Bay are known to be persistent in the environment, and fast natural attenuation is not expected. Some elements, such as lead, are in concentrations 10-100 times greater than background 


\begin{tabular}{|c|c|c|c|c|c|c|c|c|c|c|}
\hline$\stackrel{\mathbf{N}}{2}$ & & 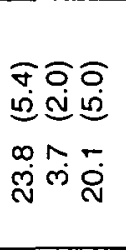 & 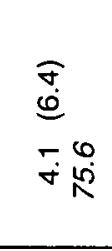 & 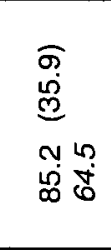 & 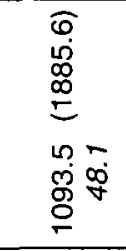 & 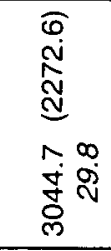 & 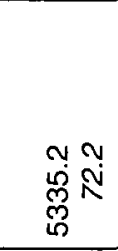 & 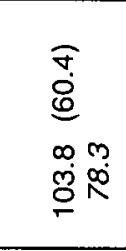 & iे & 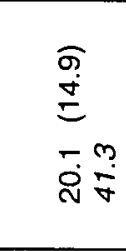 \\
\hline$\frac{0}{Q}$ & & 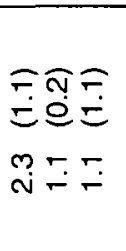 & $\frac{O}{v}$ & 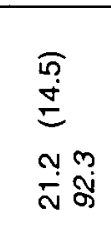 & 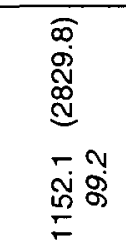 & 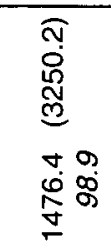 & $\begin{array}{l}\infty \\
\Phi \\
\frac{\infty}{\sigma} \\
\frac{\infty}{\sigma}\end{array}$ & 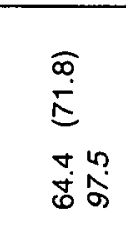 & $\stackrel{\circ}{\bar{v}}$ & $\begin{array}{l}\widehat{0} \\
\dot{\theta} \\
\stackrel{0}{\circ} \\
\dot{\forall} \\
\wedge\end{array}$ \\
\hline$\overline{\mathbf{z}}$ & & 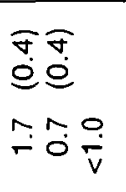 & 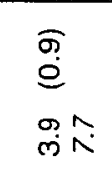 & 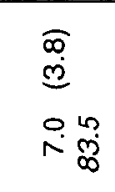 & 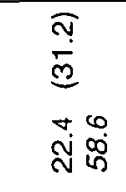 & 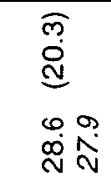 & $\begin{array}{ll}0 & 0 \\
0 & 0 \\
0\end{array}$ & $\begin{array}{l}\stackrel{\sigma}{\mathfrak{i}} \\
\dot{\nabla} \hat{\delta}\end{array}$ & ị & $\stackrel{0}{\hat{p}}$ \\
\hline$\stackrel{\Sigma}{\Sigma}$ & & 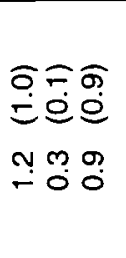 & $\begin{array}{l}\text { O̊ } \\
\stackrel{0}{=} \\
\mp 0 \\
\mp \stackrel{R}{\circ}\end{array}$ & 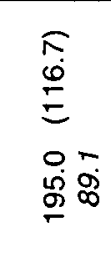 & 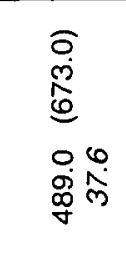 & 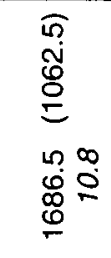 & 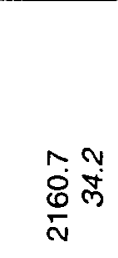 & 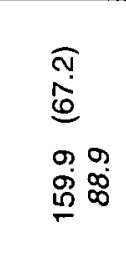 & $\stackrel{O}{\dot{v}}$ & 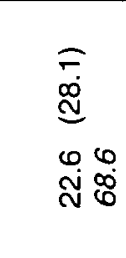 \\
\hline$\ddot{u}$ & & 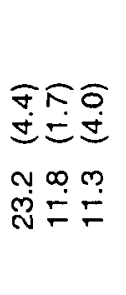 & 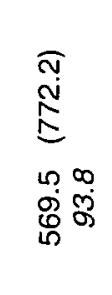 & 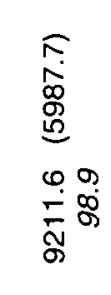 & 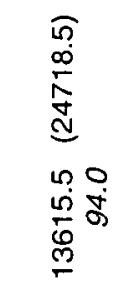 & 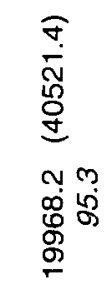 & 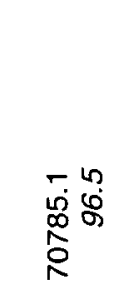 & 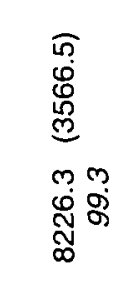 & 임 & $\stackrel{\circ}{i v}$ \\
\hline 3 & & 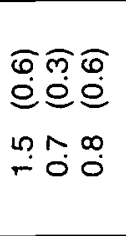 & 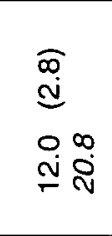 & $\begin{array}{l}\bar{N} \\
\stackrel{N}{=} \\
\bar{N} \bar{N}\end{array}$ & 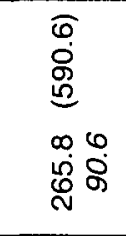 & 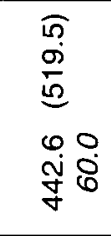 & 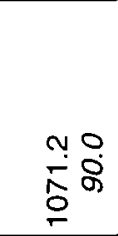 & 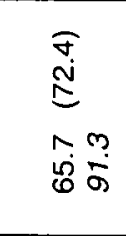 & $\stackrel{\circ}{i v}$ & 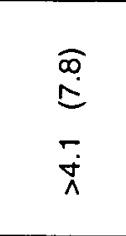 \\
\hline$\grave{\jmath}$ & & 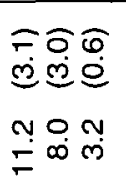 & $\begin{array}{l}\widetilde{\hat{g}} \\
\dot{g} \\
\stackrel{g}{\Gamma} \stackrel{9}{\dot{m}}\end{array}$ & 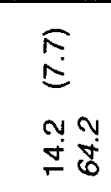 & 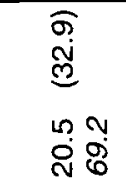 & $\begin{array}{l}\widehat{0} \\
\infty \\
0 \\
0 \\
0 \\
\infty \\
\infty \\
\dot{j} \\
\dot{\nabla}\end{array}$ & 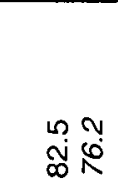 & 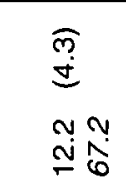 & ì & $\stackrel{\circ}{i p}$ \\
\hline 8 & & 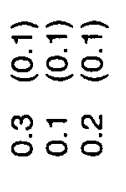 & $\begin{array}{l}\widehat{0} \\
\stackrel{0}{0} \\
\sim 00 \\
\text { i } 0 \\
\infty \\
\infty\end{array}$ & $\begin{array}{l}\widehat{\omega} \\
0 \\
\infty \\
\dot{0} \forall \\
\dot{0}\end{array}$ & 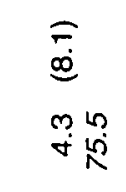 & 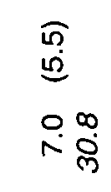 & 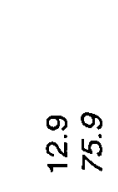 & 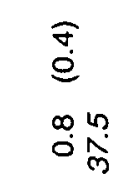 & $\frac{0}{\dot{v}}$ & $\frac{0}{\bar{v}}$ \\
\hline$\stackrel{8}{2}$ & & ت्ن & $\stackrel{\circ}{\dot{v}}$ & 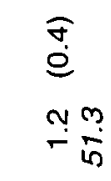 & 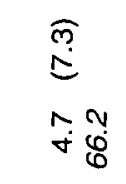 & 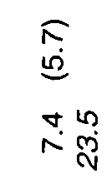 & $\begin{array}{rl}3 & 0 \\
10 & 8 \\
& 8\end{array}$ & $\frac{0}{\dot{v}}$ & $\stackrel{\circ}{\mathrm{v}}$ & $\stackrel{\stackrel{\leftrightarrow}{v}}{\mathrm{v}}$ \\
\hline & 音 & 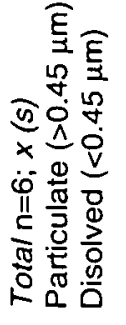 & 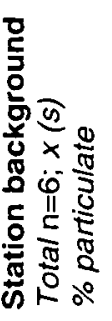 & 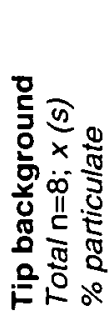 & 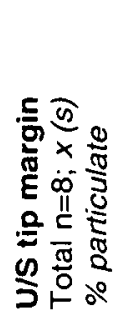 & 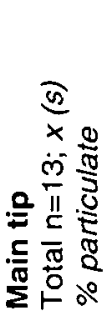 & 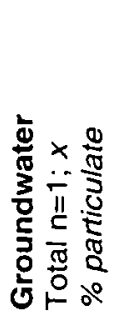 & 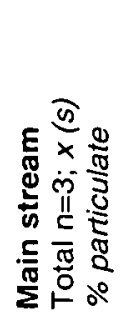 & 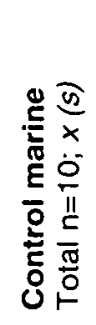 & 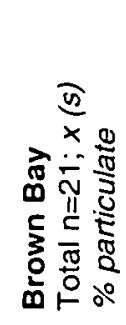 \\
\hline
\end{tabular}


Table 3. Heavy-metal concentrations $\left(\mathrm{mg} \mathrm{kg}^{-1}\right)$ in sediments from Brown Bay (impacted) and non-impacted control sites.

\begin{tabular}{|c|c|c|c|c|c|c|c|c|c|c|c|}
\hline \multirow{3}{*}{$\begin{array}{l}\text { Sample } \\
\text { ID }\end{array}$} & & & \multicolumn{7}{|c|}{$\begin{array}{c}1 \mathrm{M} \mathrm{HNO}_{3} \text { extractions } \\
\left(\mathrm{mg} \mathrm{kg}^{-1}\right)\end{array}$} & \multicolumn{2}{|c|}{$\begin{array}{c}\text { INAA } \\
\left(\mathrm{mg} \mathrm{kg}^{-1}\right)\end{array}$} \\
\hline & \multicolumn{2}{|l|}{ Location } & $\mathrm{Cu}$ & $\mathrm{Zn}$ & $\mathrm{Pb}$ & $\mathrm{Ag}$ & $\mathrm{Cd}$ & $\mathrm{Ni}$ & $\mathrm{Cr}$ & $\mathrm{Sb}$ & As \\
\hline & \multicolumn{2}{|c|}{$D L$ for reporting } & 0.26 & 0.18 & 0.78 & 0.26 & 0.10 & 0.780 & 0.260 & 0.2 & 0.6 \\
\hline PS2 & Brown Bay & Impacted & 26.58 & 72.78 & 77.05 & 0.70 & 0.82 & 3.049 & 5.425 & 1.1 & 12.3 \\
\hline PS11 & Brown Bay & Impacted & 12.18 & 45.33 & 25.67 & 0.57 & 0.55 & 2.962 & 4.642 & 0.3 & 20.4 \\
\hline PS5 & Brown Bay & Impacted & 5.8 & 61.74 & 2 & n.d. & 1.75 & 6.203 & 8.517 & 0.7 & 16.9 \\
\hline PS6 & Brown Bay & Impacted & 3.12 & 31.21 & 11.25 & n.d. & 0.39 & 2.169 & 3.075 & 0.3 & 19.4 \\
\hline PS8 & Shannon Bay & Impacted & 5.89 & 57.71 & 2.34 & 0.47 & 3.49 & 4.816 & 5.873 & 0.2 & 13.4 \\
\hline PS7 & Shannon Bay & Impacted & 3.01 & 21.73 & n.d. & n.d. & 0.86 & 3.152 & 3.846 & n.d. & 10.5 \\
\hline PS1 & Newcomb Bay & Control & 2.13 & 25.36 & 1.19 & n.d. & 0.54 & 2.826 & 3.398 & n.d. & 16.4 \\
\hline PS3 & Nr Beall Island & Control & 4.09 & 46.32 & n.d. & n.d. & 1.03 & 5.971 & 6.539 & n.d. & 33.2 \\
\hline PS4 & Nr Beall Island & Control & 2.63 & 16.92 & n.d. & n.d. & 0.67 & 2.144 & 2.312 & n.d. & 27.4 \\
\hline PS9 & Nr Beall Island & Control & 2.11 & 16.75 & n.d. & n.d. & 1.92 & 4.127 & 4.619 & n.d. & 14.0 \\
\hline PS10 & Nr Beall Island & Control & 2.49 & 27.62 & n.d. & n.d. & 1.64 & 4.170 & 4.296 & n.d. & 12.8 \\
\hline PS12 & O'Brien Bay & Control & 2.45 & n.d. & n.d. & 0.47 & 0.68 & 1.883 & 2.200 & n.d. & 11.9 \\
\hline
\end{tabular}

values, and fuel and oil have also accumulated in Brown Bay sediments. Based on the results from the pilot study, it is predicted that there will be adverse changes to the biota in the near-shore marine ecosystem, and, because most contaminants are associated with organic and inorganic particulates, it is expected that impacts in the biota will be detected most easily by studying filter-feeding and sediment-dwelling benthic organisms.

\section{Identification and monitoring of biological impacts}

Demonstrating that contaminants are in the tip and that they are being transported into the marine environment does not prove that they are having a detrimental biological impact. It is possible that they are present at concentrations
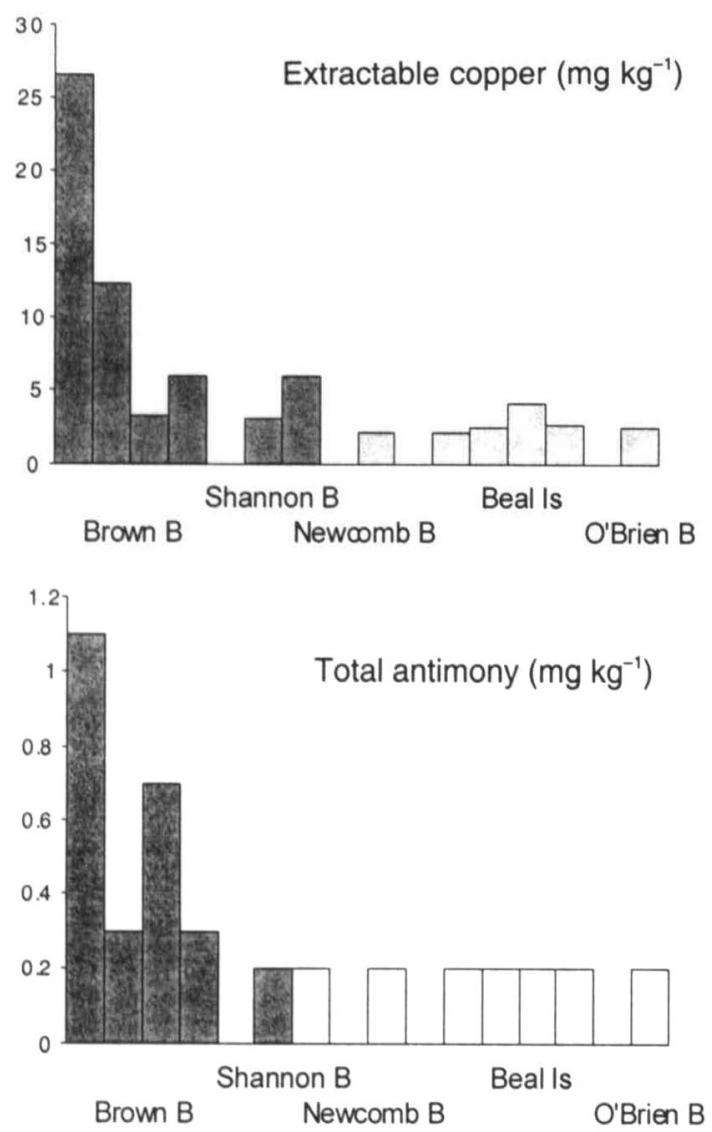

that cause no ecological effect and that natural processes of breakdown and dispersion ensure that they do not accumulate in harmful concentrations. If this is the case, the best management strategy may be to leave the tip undisturbed and allow the natural processes of remediation to follow their own course. However, under the Madrid Protocol, this passive approach to managing past wastedisposal sites is acceptable only if the site is designated as a historic site or monument or the removal of waste material by any practical option would result in greater adverse environmental impacts than leaving it. In practice, however, it is not possible to clean up all waste-disposal sites immediately and therefore clean-up needs to be prioritised, with the highest priority accorded to sites that

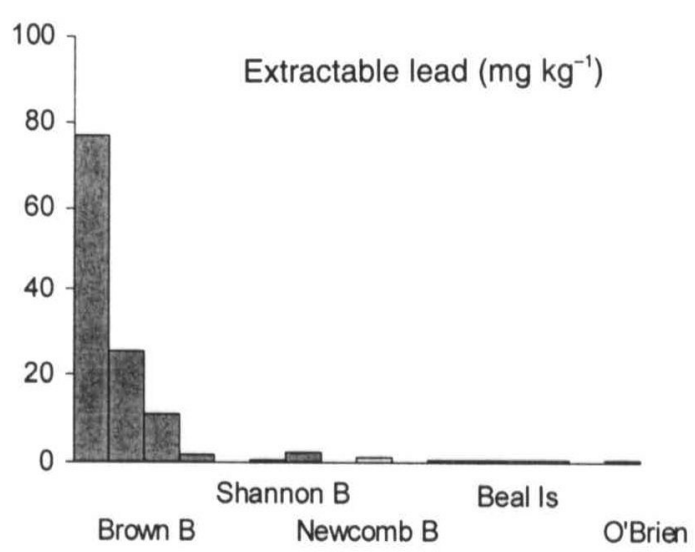

Fig. 3. Selected heavy-metal data from a pilot marine sediment survey at Casey Station. Copper, lead, and antimony were present in high concentrations in Thala Valley tip. Samples in Brown Bay are arranged in the order near, middle, and far with respect to the tip. Copper and lead concentrations are partial extractions using $1 \mathrm{M} \mathrm{HNO}_{3}$. Antimony is total concentration derived by instrumental neutron activation analysis (all concentrations are in $\mathrm{mg}$ $\mathrm{kg}^{-1}$ ). Dark gray = potentially contaminated sites; light gray $=$ contol (non-impacted) sites; white $=$ detection limits. 
are causing detrimental biological effects in the adjacent environment. Information on biological impacts is therefore necessary to determine whether clean-up should commence and as the basis of monitoring to ensure that any actions do not cause greater adverse environmental impacts.

Communities of animals and plants attached to the seabed or living in sediments are well-suited for identification and monitoring environmental impacts, because they have a fixed spatial relationship with the source of the impact and reflect the history of environmental conditions at the site for many generations past. In contrast, planktonic species or fish that are mobile and can avoid stressful conditions by moving out of the area will only reflect current or very recent conditions, because when the cause of stress passes they can return rapidly. This distinction is particularly important if the source of stress is episodic, such as a seasonal pulse of contaminants associated with the summer melt in Antarctica.

Studies of marine benthic communities adjacent to the Thala Valley tip commenced in 1996 with the objective of determining whether or not contaminated runoff has caused changes to the biota. Investigations included toxicity tests using local species to determine the concentration of contaminants that cause a toxic response, and analysis for heavy metals in various benthic invertebrates to determine whether contaminants were accumulating in body tissues. In addition, benthic communities in Brown Bay at sites close to the Thala Valley tip were compared with communities from control locations distant from Casey Station to determine whether there were differences that could be attributed to the tip. Abiotic sediments were then used to test whether conditions near the tip continue to cause differences in recruitment to benthic communities.

Toxicity testing and contaminant accumulation in biota Toxicity tests estimate the concentration of a contaminant that produces observable detrimental effects in an organism. In such tests, the concentration that either kills (lethal concentration; LC) or causes a measurable sub-lethal response (effective concentration, EC) on a certain percentage of the test population after a specified time is determined. Toxicity tests have been used to estimate acceptable levels of contaminants in the environment in tropical and temperate regions and have played an integral part in the development of environmental guidelines in these regions. Very few toxicity tests have been undertaken using Antarctic species, so there is little information to assess whether guidelines developed elsewhere are appropriate for the Antarctic or whether contaminant concentrations measured in the Antarctic should be cause for concern. In toxicity tests with the common Antarctic amphipod Paramorea walkeri, LC50 values following exposure for four days were $970 \mu \mathrm{g} \mathrm{I}^{-1}$ for copper and 670 $\mu \mathrm{g} \mathrm{I}^{-1}$ for cadmium (Duquesne and others 2000). These values are within the range previously measured for similar non-Antarctic amphipods suggesting that this Antarctic species is no more sensitive to these metals than species from elsewhere. A sub-lethal test, based on development of sea urchins to the pluteus larval stage, is commonly used in temperate regions and was modified for use with the Antarctic sea urchin Sterechinus neumayeri (King and Riddle, in press). Concentrations of metals causing a 50\% reduction (EC50) in the normal development of embryos of $S$. neumayeri to the pluteus stage were $1.4 \mu \mathrm{g} \mathrm{l}^{-1}$ for copper and $327 \mathrm{~g} \mathrm{I} \mathrm{l}^{-1}$ for zinc. Exposure to $200 \mathrm{\mu g}^{-1}$ cadmium caused a significant decrease in the proportion of normal plutei. In comparison to sea urchins from tropical and temperate regions, the Antarctic species is more sensitive to cadmium and is $5-10$ times more sensitive to copper, although it is relatively insensitive to zinc (King and Riddle, in press).

Tissue from various marine invertebrates collected near Thala Valley and at control locations were analysed for a suite of heavy metals, including arsenic, cadmium, chromium, copper, nickel, lead, and zinc (Duquesne and Riddle, in press), some of which are present in high concentrations in the tip. As animals interact with contaminants in different ways depending on their methods of feeding and habitat (Table 4), the species used in this study were selected to be representative of different feeding modes found in Antarctic benthic communities. Concentrations of contaminants in the different species therefore provide information on the availability of contaminants to different functional components of the biota.

Contaminant levels in tissues of animals that feed on suspended particles, such as Paramorea walkeri and Laternula elliptica, should rise and fall rapidly in response to pulses of contaminated particles in the water column. Contaminants in animals that feed on sea-bed deposits, such as the heart urchins Abatus nimrodi and $A$. ingens, should change less quickly because contaminant levels in the sediment will change much more slowly than levels in the water column. Contaminant levels in predators, such as the sea-star Notasterias armata, should indicate aggregate levels of contaminants over time and across species.

In all species, lead and zinc concentrations were consistently higher in tissues from animals collected close to Thala Valley than in tissues from animals collected from control locations (Duquesne and Riddle, in press). Other metals were in higher concentrations in specimens from near Thala Valley in some but not all species. For example, arsenic and copper concentrations in specimens collected near Thala Valley were significantly higher in the heart urchin A. nimrodi and the bivalve L. elliptica, and cadmium was higher in heart urchins. Of the 20 combinations of species and metals tested, 11 were higher in specimens collected near Thala Valley and only three were higher at the control localities (arsenic in N. armata, and chromium and nickel in $A$. nimrodi). Of those where metals were higher in control locations, concentration differences were small and the metals were not those most prevalent in the tip (see Table 1). Nickel was the only metal analysed that was not in significantly higher concentrations in specimens 
Table 4. Antarctic invertebrates with different feeding modes that live in different habitats are exposed to contamination in a variety of ways.

\begin{tabular}{|llll|}
\hline Species & Habitat & Feeding mode & Exposure to contaminants \\
\hline $\begin{array}{l}\text { Amphipod } \\
\text { Paramorea walkeri }\end{array}$ & $\begin{array}{l}\text { Sea-ice/water } \\
\text { and water/sediment } \\
\text { interfaces }\end{array}$ & $\begin{array}{l}\text { Scavenger, } \\
\text { selective particle } \\
\text { feeder }\end{array}$ & $\begin{array}{l}\text { Transient - exposed to contaminants } \\
\text { adsorbed to particles in suspension } \\
\text { and to dissolved contaminants }\end{array}$ \\
\hline $\begin{array}{l}\text { Bivalve } \\
\text { Laternula elliptica }\end{array}$ & $\begin{array}{l}\text { In sediment at } \\
\text { sea-bed/water } \\
\text { interface }\end{array}$ & $\begin{array}{l}\text { Active filterer, } \\
\text { non-selective } \\
\text { particle feeder }\end{array}$ & $\begin{array}{l}\text { Transient - exposed to contaminants } \\
\text { adsorbed to settling and } \\
\text { re-suspended particles }\end{array}$ \\
\hline $\begin{array}{l}\text { Heart urchin } \\
\text { Abatus nimrodi, } \\
\text { Abatus ingens }\end{array}$ & $\begin{array}{l}\text { In sediment } \\
\text { beneath sea-bed }\end{array}$ & $\begin{array}{l}\text { Selective } \\
\text { deposit feeder }\end{array}$ & $\begin{array}{l}\text { Long-term - exposed to contaminants } \\
\text { adsorbed to sediment particles and } \\
\text { dissolved in pore water }\end{array}$ \\
\hline $\begin{array}{l}\text { Sea-star } \\
\text { Notasterias armata }\end{array}$ & Sea-bed surface & Predator & $\begin{array}{l}\text { Long-term - exposed to contaminants } \\
\text { in tissues of prey }\end{array}$ \\
\hline
\end{tabular}

from near the waste site in at least one species. Overall these results indicate that metal contaminants from the tip have accumulated in the body tissues of animals.

\section{Impacts on biological communities}

Having identified that concentrations of contaminants in the environment are at levels likely to cause a toxic response and having confirmed that the biota in Brown Bay are not only exposed to contaminants but are accumulating them in their body tissues, the final step in determining whether the tip has caused an impact on the local biota is to test whether the biological communities in Brown Bay are different from those found in comparable sites away from the tip. The communities living within sediments were used for this component of the study, as they are widely accepted as sensitive indicators of environmental stress (for example, Underwood and Peterson 1988).

Hand-held corers were used by divers to collect sediments from patches of muddy sand at each of four control and four potentially impacted locations (Stark and Riddle, in press). The four potentially impacted locations were Brown Bay, which was sampled at several sites; Shannon Bay adjacent to the sewage outfall; near an area of fuel contamination at the Casey wharf; and adjacent to an abandoned waste-disposal site at Wilkes Station (see Fig. 1). A hierarchical nested sampling design was used with two sites 100-200 $\mathrm{m}$ apart at each location; at each site were two plots of $1-2 \mathrm{~m}$ in diameter, about $10-20 \mathrm{~m}$ apart; and four replicate samples were taken from each plot. Animals retained by a $1 \mathrm{~mm}$ mesh sieve were identified to the highest and most convenient level of taxonomic resolution (Stark 2000).

Multivariate analysis (non-metric multidimensional scaling on similarity matrices calculated with the BrayCurtis similarity measure after fourth root transformation of abundances; Clarke and Green 1988) revealed two distinct groups of samples: the potentially impacted locations and the control locations (Fig. 4). Analysis of similarity (Clarke and Warwick 1994; Clarke 1993) indicated that these two groups are significantly different and multivariate analysis of variability (the index of multivariate dispersion; Clarke and Warwick 1994) indicated that the assemblages at impacted locations were less variable than at control locations (Stark 2001). Analysis of variance of several community-level parameters (number of taxa, number of individuals, Shannon-Weiner diversity, richness, and evenness) and on the number of individuals of various phyla, orders, genera, and species indicated significant differences at all three spatial scales (locations, sites, and plots; Fig. 5, Table 5). Differences within locations (between sites and plots) were often as great as differences between locations, indicating that the communities are very patchy. However, studies by Stark $(2000,2001)$ noted that some consistent patterns did emerge:

- There are significant differences in soft-sediment assemblages between control and impacted locations, and all impacted locations are more similar to each other than to control locations.

- Number of species, species diversity, and richness of the benthic fauna were lower at impacted locations than at control locations.

- There were consistent differences in the variability of impacted and control locations; assemblage composition was less variable at the impacted sites and the abundances of individual taxa were generally more variable.

- The abundance of several taxa was significantly different between control and impacted locations. For example, many taxa occurred only at control locations.

- One taxon that occurred only at the impacted locations, capitellid polychaetes, is known to be associated with disturbed and polluted areas in other Antarctic localities (Lenihan and Oliver 1995), in sub-Antarctic regions (Smith and Simpson 1995), and in temperate regions (for example James and Gibson 1980; Stark 1998).

These results do not prove a priori that the differences between Brown Bay and the control locations were caused by contaminants from Thala Valley, because quantitative information is not available from the period before the tip was established. Recruitment experiments using clean and 
a)

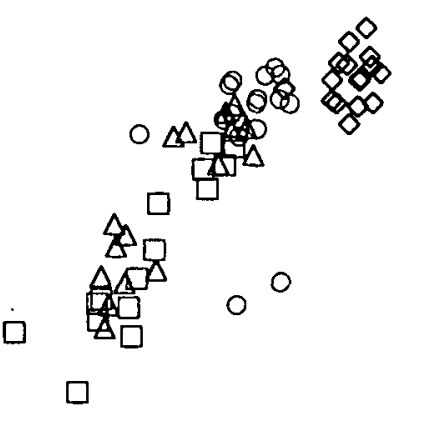

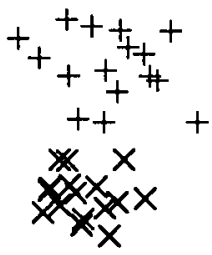

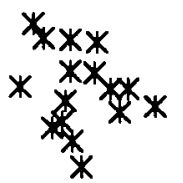

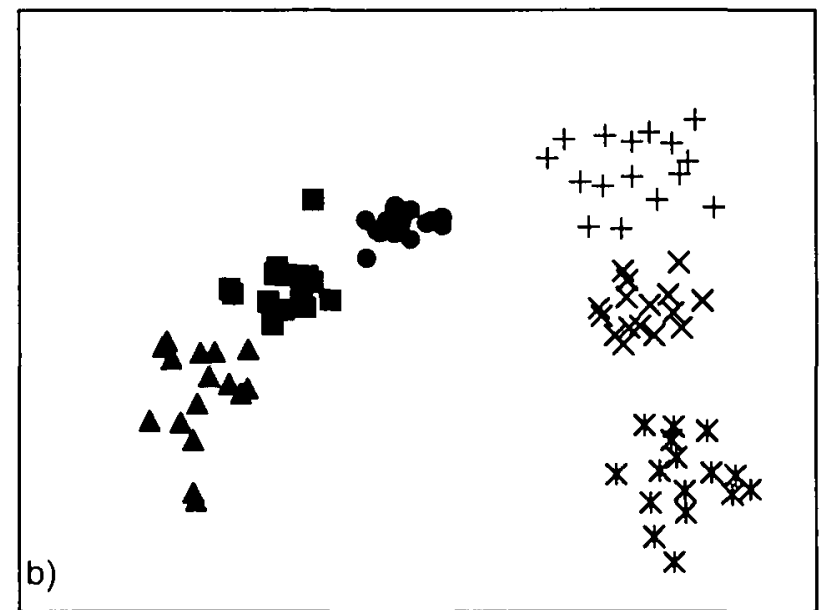

\begin{tabular}{|l|}
\hline O Old Casey Tip (Inner) \\
$\square$ Old Casey Tip (Middle) \\
$\Delta$ Old Casey Tip (Middle) \\
o Old Casey Tip (Outer) \\
- Sewage Outfall \\
$\Delta$ Casey Wharf \\
$\square$ Wilkes Tip \\
$*$ Control 1 \\
$\times$ Control 2 \\
+ Control 3
\end{tabular}

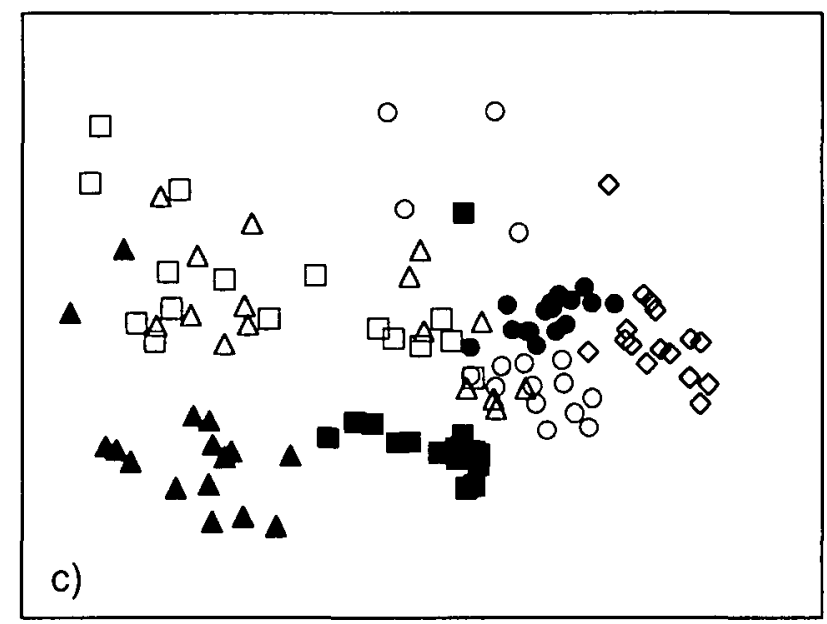

Fig. 4. Multidimensional scaling ordinations comparing the composition of benthic assemblages in samples from the Casey region: a) Thala Valley tip (Brown Bay) compared to three control locations, stress $=0.13$; b) Shannon Bay sewage outfall, Casey wharf, and Wilkes tip compared to the three control locations, stress $=0.11 ; \mathrm{c}$ ) all impacted locations, Brown Bay, Shannon Bay, wharf, and Wilkes, stress $=0.14$ (data from Stark 2001).

contaminated sediments further indicated that contamination similar to that in sediments from Brown Bay is sufficient to cause significant differences in recruitment of benthic invertebrates (Stark and co-workers, unpublished data). Taken in combination, the results of the benthic community study strongly support the contention that an impact to biota has occurred at Brown Bay, Shannon Bay, the wharf, and Wilkes. The survey also indicates the scale of spatial replication necessary for the monitoring of clean-up operations to ensure that significant differences are not masked by natural variability and patchiness.

\section{Conclusions and implications}

The conclusion from the biological investigations is that contaminants from Thala Valley tip are highly likely to be causing impacts on the benthos of Brown Bay. The few available toxicity tests using Antarctic species indicate they are at least as sensitive as temperate species to heavymetal contaminants. As a consequence, environmental contamination that exceeds guidelines developed in betterstudied temperate regions should be a concern, and the development of specific guidelines for Antarctica should be undertaken. Levels in body tissues indicate that animals are exposed to contaminants in biologically available forms, and differences in community structure and recruitment are consistent with exposure to heavy-metal contamination seen in other regions.

\section{Summary and recommendations}

Partial removal of the Thala Valley Tip material in 199596 without construction of a bunding is likely to have caused several adverse environmental impacts. Excavation and physical disturbance by heavy vehicles exposed pockets of concentrated contaminants to flowing melt-water and resulted in transport of a greater than normal contaminant load into Brown Bay. Partially removing the large debris from the tip by scraping from the surface and leaving behind the finer material has left a site that is occasionally inundated by marine water, creating further opportunities for washing contaminants into the bay. In addition, a previously uncontaminated site, used as a temporary storage depot for waste, may have become contaminated because the storage containers used were not sealed and were allowed to thaw prior to return to Australia.

Although the recommendations arising from the identification and assessment of contaminated sites (Deprez and others 1994, 1999) were consistent with environmental obligations, they were not closely followed. As a direct 

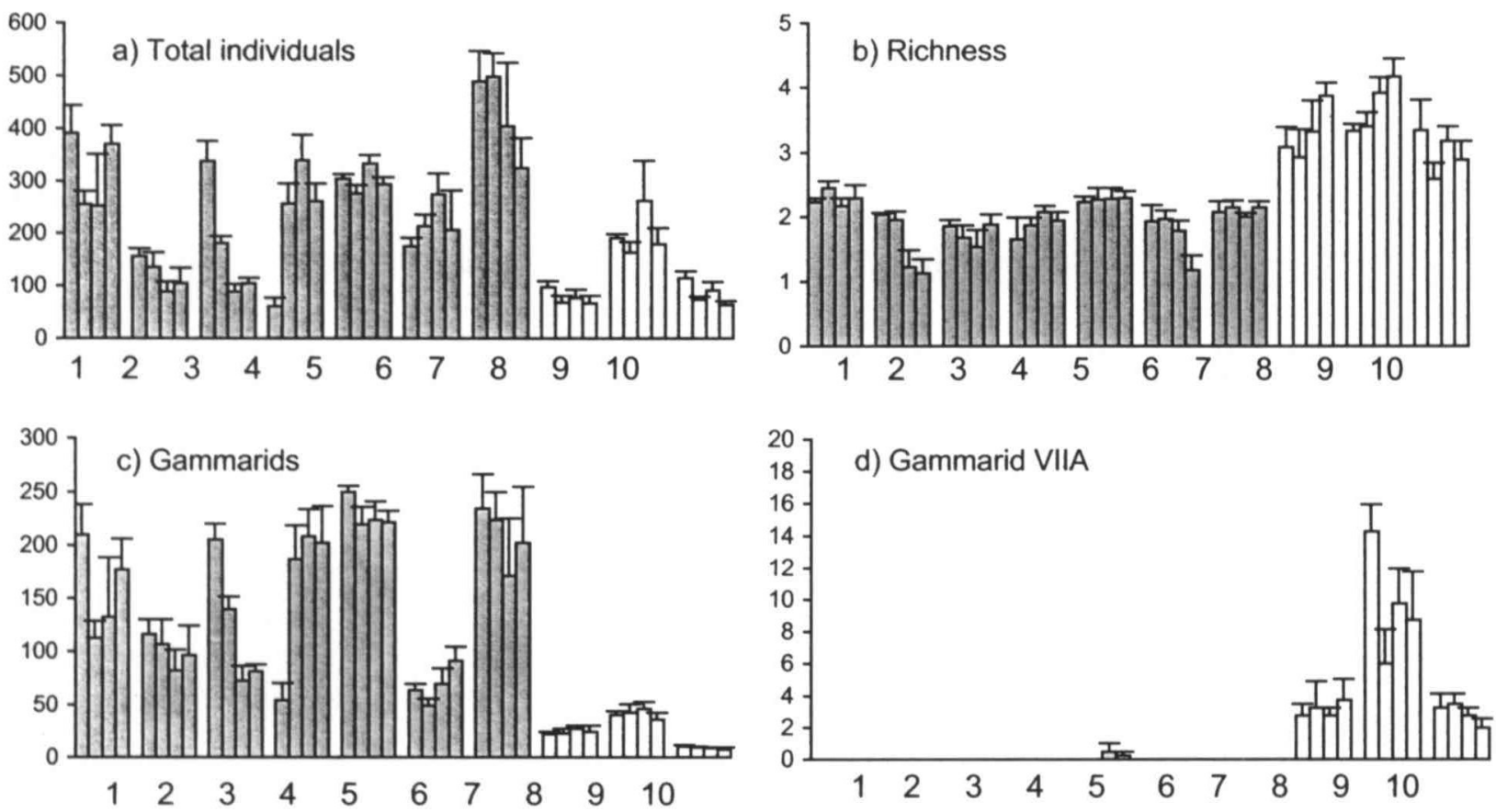

Fig. 5. Histograms representing the mean values per core sample $(n=4)$ in each plot, within each site, within each location: a) total number of individuals; b) richness; c) gammarids; d) gammarid VIIA. Dark bars = impacted locations; light bars $=$ control locations. There are four plots shown per location, two within each of two sites within each location. $1=$ Brown Bay inner; 2 = Brown Bay middle; 3 = Brown Bay middle; 4 = Brown Bay outer; $5=$ Shannon Bay; $6=$ Casey wharf; $7=$

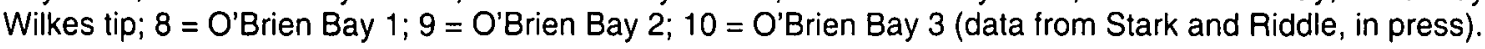

consequence, the flux of contaminants into Brown Bay has been exacerbated and at least one additional contaminated site may have been created. Removal of the remaining waste and remediation of contaminated soils still remain to be completed. Thala Valley should be given the highest priority because this study indicates that the tip still contains apprt ciable heavy metals that are actively moving into Brown Bay and that impacts to marine biota are occurring. To consider how best to manage Thala Valley in the context of other high-priority sites (especially Wilkes), a

Table 5. Summary of results from asymmetrical analysis of variances (ANOVAs) comparing disturbed locations to control locations. $-=$ nol significant, ${ }^{*}=p<0.05,{ }^{\star \star}=p<0.01,{ }^{\star \star \star}=p<0.001 .{ }^{1}=$ analysis by symmetrical three-factor ANOVA and Student-Newman-Keuls test. ${ }^{2}=$ taxa not present at lesser location(s) (data from Stark 2001).

\begin{tabular}{|c|c|c|c|c|c|c|c|}
\hline Taxa & $\begin{array}{l}\text { Between } \\
\text { controls }\end{array}$ & $\begin{array}{c}\text { Brown Bay } \\
\text { inner vs } \\
\text { controls }\end{array}$ & $\begin{array}{c}\text { Brown Bay } \\
\text { middle vs } \\
\text { controls }\end{array}$ & $\begin{array}{c}\text { Brown Bay } \\
\text { outer vs } \\
\text { controls }\end{array}$ & $\begin{array}{c}\text { Shannon } \\
\text { vs } \\
\text { controls }\end{array}$ & $\begin{array}{l}\text { Wharf vs } \\
\text { controls }\end{array}$ & $\begin{array}{l}\text { Wilkes vs } \\
\text { controls }\end{array}$ \\
\hline Total taxa & - & - & - & - & - & - & - \\
\hline Shannon diversity $\left(\mathrm{H}^{\prime}\right)$ & ** & - & - & $\mathrm{C}>\mathrm{BBO}^{* 1}$ & C>Shan*1 & C> Wharf**1 & - \\
\hline Richness (d) & - & $\mathrm{C}>\mathrm{BBI}^{*}$ & $\mathrm{C}>\mathrm{BBM}^{\star *}$ & $\mathrm{C}>\mathrm{BBO}^{* *}$ & C>Shan* & C>Whart** & C>Wilkes* \\
\hline Evenness $\left(J^{\prime}\right)$ & 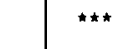 & - & - & - & C>Shan*1 & C>Whar*1 & - \\
\hline Total individuals & $\star \star$ & - & - & - & - & - & Wilkes $>C^{\star 1}$ \\
\hline Crustaceans & $\star \star \star *$ & - & - & - & - & - & Wilkes $>C^{\star 1}$ \\
\hline Gammarids & ** & $\mathrm{BB} \mid>\mathrm{C}^{\star \star 1}$ & $\mathrm{BBM}>\mathrm{C} * * 1$ & $\mathrm{BBO}>\mathrm{C}^{* * 1}$ & Shan $>C * * 1$ & Wharf>C*1 & Wilkes $>C^{\star 1}$ \\
\hline Orchomenella franklini & - & $\mathrm{BB} \mid>\mathrm{C}^{\star}$ & $\mathrm{BBM}>\mathrm{C}^{\star \star}$ & $\mathrm{BBO}>\mathrm{C}^{\star \star}$ & Shan $>C^{\star}$ & - & Wilkes $>C^{* * *}$ \\
\hline Orchomenella sp. IIA & - & $\mathrm{BB} \mid>\mathrm{C}^{2}$ & $\mathrm{BBM}>\mathrm{C}^{2}$ & $\mathrm{BBO}>\mathrm{C}^{2}$ & Shan $>C^{2}$ & Wharf $>C^{2}$ & Wilkes $>C^{2}$ \\
\hline Methalimedon sp. IV & - & $\mathrm{BB} \mid>\mathrm{C}^{\star \star}$ & - & - & Shan $>C^{*}$ & C> Whart ${ }^{2}$ & Wilkes $>C^{* 1}$ \\
\hline Paroediceroides sp. VI & $*$ & - & - & $\mathrm{C}>\mathrm{BBO}^{2}$ & C>Shan ${ }^{2}$ & C> Wharf ${ }^{2}$ & C>Wilkes ${ }^{2}$ \\
\hline Paraperioculoides sp. & - & - & $\mathrm{C}>\mathrm{BBM}^{2}$ & - & - & C> Whart ${ }^{2}$ & C> Wilkes ${ }^{2}$ \\
\hline Tanaids & * & - & - & - & - & C>Wharf*1 & - \\
\hline Nototanais & ** & - & - & - & - & - & Wilkes $>C^{\star 1}$ \\
\hline Ostracods & ** & & - & - & - & - & - \\
\hline Ostracodsp. I & * & - & $\mathrm{C}>\mathrm{BBM}^{2}$ & - & - & C> Whart ${ }^{2}$ & C>Wilkes ${ }^{2}$ \\
\hline Isopods & - & $\mathrm{BBI}>\mathrm{C}^{\star \star \star}$ & - & $\mathrm{BBO}>\mathrm{C}^{*}$ & Shan $>C^{\star}$ & - & Wilkes $>C^{\star \star \star *}$ \\
\hline Copepods & - & - & - & $\mathrm{BBC}$ & Sha & $\mathrm{I}>\mathrm{C}^{*}$ & Wilkes $>\mathrm{C}^{\star \star}$ \\
\hline Polychaetes & * & - & - & - & - & Wharf $>C^{* 1}$ & - \\
\hline Echinoderms & ** & - & $\mathrm{C}>\mathrm{BBM}^{2}$ & - & - & C> Whart ${ }^{2}$ & C> Wilkes ${ }^{2}$ \\
\hline Gastropods & ** & - & & - & - & - & Wilkes $>C^{\star 1}$ \\
\hline Bivalves & * & - & $\mathrm{C}>\mathrm{BBM}^{2}$ & - & - & - & C> Wilkes ${ }^{2}$ \\
\hline
\end{tabular}


Table 6. Five options for the management of Australia's contaminated sites in Antarctica.

\begin{tabular}{|c|c|c|c|c|}
\hline Option & Scope & Cost & $\begin{array}{l}\text { Environmental } \\
\text { impact }\end{array}$ & $\begin{array}{l}\text { Time- } \\
\text { frame }\end{array}$ \\
\hline Do nothing & Leave sites untouched & Nil & On-going & $\begin{array}{l}\text { Decision is } \\
\text { reversible }\end{array}$ \\
\hline $\begin{array}{l}\text { Opportunistic } \\
\text { clean-up }\end{array}$ & $\begin{array}{l}\text { Remove material in an ad } \\
\text { hoc manner when people } \\
\text { or equipment are available }\end{array}$ & Minimal & $\begin{array}{l}\text { On-going, potential } \\
\text { to increase }\end{array}$ & $\begin{array}{l}\text { Long-term, } \\
\text { possibly } \\
\text { on-going }\end{array}$ \\
\hline $\begin{array}{l}\text { Clean up sites } \\
\text { already disturbed }\end{array}$ & $\begin{array}{l}\text { Remove the primary } \\
\text { sources of contamination at } \\
\text { Thala Valley only }\left(\sim 2500 \mathrm{~m}^{3}\right) \\
\text { and monitor impacts, } \\
\text { contaminated soils remain }\end{array}$ & Moderate & $\begin{array}{l}\text { Reducing at specific } \\
\text { sites, some residual } \\
\text { contamination }\end{array}$ & $\begin{array}{l}1 \text { or } 2 \\
\text { summer } \\
\text { seasons }\end{array}$ \\
\hline $\begin{array}{l}\text { Clean up } \\
\text { all sites }\end{array}$ & $\begin{array}{l}\text { Remove only the primary } \\
\text { sources of contamination } \\
\text { at all sites }\left(\sim 50,000 \mathrm{~m}^{3}\right) \\
\text { and monitor impacts, } \\
\text { contaminated soils remain. }\end{array}$ & Significant & $\begin{array}{l}\text { Reducing at all sites, } \\
\text { some residual } \\
\text { contamination }\end{array}$ & $-5-10$ years \\
\hline $\begin{array}{l}\text { Clean up and } \\
\text { remediate all } \\
\text { sites }\end{array}$ & $\begin{array}{l}\text { Remove the primary } \\
\text { sources of contamination } \\
\text { at all sites }\left(\sim 50,000 \mathrm{~m}^{3}\right), \\
\text { remediate contaminated } \\
\text { soils and monitor impacts. }\end{array}$ & $\begin{array}{l}\text { Significant } \\
\text { but not } \\
\text { considerably } \\
\text { greater than } 4\end{array}$ & Reducing at all sites & $\sim 10-20$ years \\
\hline
\end{tabular}

number of options have been identified (Table 6).

\section{Do nothing}

To do nothing would be the best option if there are not the techniques to clean up without causing greater adverse environmental impacts or if cost-benefit analysis indicates that our efforts should be directed to other more serious or more urgent environmental problems. Our results indicate that this is not the case for Thala Valley tip - it is unlikely that removal operations could cause further environmental harm, because the site is already highly disturbed and large quantities of waste or contaminants in leachate are transported into Brown Bay each year. Thala Valley tip is a high priority in comparison with any of our other contaminated sites and if clean-up cannot be completed there because of technical or logistic constraints, other sites should not be disturbed.

\section{Opportunistic clean-up}

Ad hoc clean-up using available resources without dedicating people or equipment is unlikely to produce environmentally acceptable results. Past experience indicates that clean-up operations can cause greater environmental impacts unless they are carefully managed. It will also take many seasons for a clean-up to be completed without dedicated resources, during which time mobilisation of contaminants by summer melt water will continue to cause impacts in Brown Bay. Opportunistic clean-up is not recommended for Thala Valley or for other abandoned work sites and disused waste-disposal sites.

\section{Clean up only those sites that have already been disturbed}

Adoption of this approach is acknowledgement that previous clean-up attempts were a failure, and suggests that the best that can be done is to tidy up after past mistakes. This is not the case, the reasons for commencing work at Thala Valley in 1995-96 are still valid, and if clean-up there can be completed successfully the techniques should be directed towards other, larger, and more complex sites such as Wilkes (Snape and others 1998). This option, and the two that follow, all require procedures to manage groundwater runoff through the site and to control marinewater ingress during removal operations. Permeable reactive barriers, particle separation technology, and wastewater treatment using a portable vacuum distillation unit are all being considered and tested for managing groundwater (see Snape and others 2000; Morris and others 2000). Barriers consisting of a retaining wall to support geotextiles are being designed to enclose the seaward end of the tip and prevent marine-water ingress and consequent flushing of tip fines into the bay (Snape and others, in press).

\section{Finish clean-up of Thala Valley and commence at other sites}

This approach treats comprehensive clean-up at Thala Valley as a trial to develop procedures and to assess recovery of contaminated sites as a precursor to working elsewhere. If the trial is not successful and Thala Valley cannot be managed without causing greater environmental harm, additional research will be necessary to support the development of effective procedures that comply with Annex III of the Madrid Protocol.

\section{Clean up Thala Valley and other sites, including} remediation of soils contaminated with fuel

This approach involves complete clean-up of contaminated sites by removal of all primary contaminant sources. In 
addition, the comprehensive rehabilitation of sites would also need to be undertaken. Research described above to quantify the rate of natural attenuation of petroleum spills at the Old Casey workshop/powerhouse site indicates that intrinsic petroleum breakdown occurs only very slowly in Antarctica (see also Gore and others 1999). Because of this, active manipulation of environmental conditions to encourage in situ remediation of soils contaminated with hydrocarbons from spilt fuel and oil is needed. In situ remediation techniques are not yet fully developed for Antarctic conditions; however, several long-term field trials have been initiated to assess the viability of, and risks associated with, nutrient amendments and chemical treatments to increase the rate of degradation (Snape and others 2000). A full-scale trial to test the effectiveness of procedures should be possible in three to five years.

\section{Conclusions}

Until this study, the clean-up of contaminated sites in Antarctica has been seen as a logistical problem, limited by the ability to move large volumes of material from a remote region. The mechanisms for causing greater environmental impacts have not previously been recognised, hence the techniques for monitoring potential impacts have not been developed and the practical problems of excavation and removal without causing greater environmental harm have not been addressed. As a consequence most clean-ups have proceeded without adequate precautions and without effective monitoring.

This study has provided information to guide the completion of the clean-up of Thala Valley and to indicate how other similar sites should be assessed and managed. Preliminary results from site-specific toxicology studies, linked to observations of ecological variability and anthropogenic change in the region led to the conclusion that past waste-management practices affected biota in Brown Bay. It is also likely that impacts will continue to occur if further remedial action is not taken. The next stage is to develop the theory into an operational plan to include detailed protocols for clean-up, monitoring, site remediation, and management of the waste stream from site to final repository. The plan will require cost estimates and consideration of accountability, including a clearly defined chain of command and contingency plans. To achieve this, the Australian Antarctic Division has established a contaminated sites taskforce that will facilitate the transition from research and development of techniques to implementation of the most appropriate clean-up options.

\section{Acknowledgements}

This research was undertaken through the generous support of Antarctic Science Advisory Committee grants 1163 , 1089, 2179 and 2201. The authors would also like to acknowledge and thank the following for their help and technical support: Norm Pearson and Ashwini Sharma (GEMOC ICP-MS facility); Blair Hoestetler; Richard Abercherli and Richard Giles (Chemistry Department, Macquarie University); Michael Wu (AGAL ICP-MS facility, Sydney); and Paul Goldsworthy, Andrew Tabor, Johnston Davidson, Jibba Nixon, Brian Harold, Simon Pearce, Tim Ryan, Susan Doust, Gillian Anderson, Beck Scouller, and Nadia Babicka (Australian Antarctic Division). We would also like to thank the two anonymous reviewers of the manuscript.

\section{References}

Acero, J.M., J.L. Agraz, and C.A. Aguirre. 1996. Environmental review of Argentine activities at Esperanza (Hope Bay), Antarctic Peninsula. Buenos Aires: Instituto Antártico Argentino (Publication 26).

Agraz, J.L., R.A. Sánchez, C.A. Rinaldi, and J.M. Acero. 1998. Environmental review of Argentine activities at Marambio Station. (XXII ATCM/IP49).

ANZECC. 1992. Australian water quality guidelines for fresh and marine waters. Australian and New Zealand Environment and Conservation Council/National Health and Medical Research Council.

ANZECC/NH\&MRC. 1992. Australian and New Zealand guidelines for the assessment and management of contaminated sites. Australian and New Zealand Environment and Conservation Council/National Health and Medical Research Council.

ANZECC and ARMCANZ. 2000. National water quality management strategy: Australian and New Zealand guidelines for fresh and marine waterquality. Volume 1. http://www.erin.gov.au/science/water/volume 1.pdf

ATCPs. 1993. Protocol on Environmental Protection to the Antarctic Treaty. Polar Record 29 (170): 256-275; SCAR Bulletin 110.

Babicka, N.A., P.M. Goldsworthy, and I. Snape. 2000. Contaminants in the Antarctic environment IX: GIS as a tool to assist with the management of contaminated sites. In: Hughson, T., and C. Ruckstuhl (editors). ISCORD 2000: Proceedings of the sixth international symposium on cold region development. Hobart: International Association of Cold Regions Development Studies: $130-134$

Batley, G.E., and W.A. Maher. In press. The development and application of ANZECC sediment quality guidelines. Australasian Journal of Ecotoxicology.

Clarke, K.R. 1993. Non-parametric multivariate analysis of changes in community structure. Australian Journal of Ecology 18: 117-143.

Clarke, K.R., and R.H. Green. 1988. Statistical design and analysis for a biological effects study. Marine Ecology Progress Series 46: 213-226.

Clarke, K.R., and R.M. Warwick. 1994. Change in marine communities: an approach to statistical analysis and interpretation. Plymouth: Plymouth Marine Laboratory, Natural Environment Research Council.

Cole, C.M., I. Snape, D.B. Gore, A.T. Revill, and M.J. Riddle. 2000. Contaminants in the Antarctic environment III: chemical and physical processes that influence contaminants in cold regions. In: Hughson, T., and C. Ruckstuhl (editors). ISCORD 2000: Proceedings of the sixth international symposium on cold region development. Hobart: International Association of Cold Regions Development Studies: 128-131.

COMNAP. 2000. Standard techniques for monitoring in Antarctica. Council of Managers of National Antarctic Programs. www.comnap.au

Deprez, P.P., M. Arens, and H. Locher. 1994. Identification and preliminary assessment of contaminated sites in 
the Australian Antarctic Territory. 1. Casey Station. Kingston, Tasmania: Australian Antarctic Division.

Deprez, P.P., M. Arens, and H. Locher. 1999. Identification and assessment of contaminated sites at Casey station, Wilkes Land, Antarctica. Polar Record 35 (195): 299316.

Duquesne, S., M.J. Riddle, R. Schulz, and M. Liess. 2000. Effects of contaminants in the Antarctic environment: potential of the gammarid amphipod crustacean Paramorea walkerias a biological indicator for Antarctic ecosystems based on toxicity and bio-accumulation of copper and cadmium. Aquatic Toxicology 49: 131-143.

Duquesne, S., and M.J. Riddle. In press. Biological monitoring of heavy metal contamination in coastal waters in the vicinity of Casey Station, Windmill Islands, East Antarctica. Polar Biology.

Gasparon, M. 1998. Trace metals in water samples: minimising contamination during sampling and storage. Environmental Geology 36: 207-214.

Gore, D.B., A.T. Revill, and D. Guille. 1999. Petroleum hydrocarbons ten years after spillage at a helipad in Bunger Hills, East Antarctica. Antarctic Science 11: 428-430.

Guille, D., A. Revill, and J. Bowman. 1997. Long-term fate of petroleum contaminations at Casey station, Antarctica. Hobart: CSIRO Marine Research.

James, C.J., and R. Gibson. 1980. The distribution of the polychaete Capitella capitata (Fabricius) in dock sediments. Estuarine and Coastal Marine Science 10: 671-683.

King, C.K., and M.J. Riddle. In press. Effects of metal contaminants on the embryonic and larval development of the common Antarctic sea urchin Sterechinus neumayeri(Meissner). Marine Ecology Progress Series.

Lenihan, H.S., and J.S. Oliver. 1995. Anthropogenic and natural disturbances to marine benthic communities in Antarctica. Ecological Applications 5 (2): 311-326.

Morris, C.E., C.M. Cole, I. Snape, and P.P. Deprez. 2000. Contaminants in the Antarctic environment VIII: problems of contaminated site clean-up and engineering solutions. In: Hughson, T., and C. Ruckstuhl (editors). ISCORD 2000: Proceedings of the sixth international symposium on cold region development. Hobart: International Association of Cold Regions Development Studies.

Morrisey, D.J., A.J. Underwood, J.S. Stark, and L. Howitt. 1994. Temporal variation in concentrations of heavy metals in marine sediments. Estuarine, Coastal and Shelf Science 38: 271-282.

Pickard, J. (editor). 1986. Antarctic oasis: terrestrial environments and history of the Vestfold Hills. Sydney: Academic Press.

Reed, S.C., and R.S. Sletten. 1989. Waste management practices of the United States Antarctic Program. Hanover, NH: US Army Cold Regions Research and Engineering Laboratory (CRREL Special report 89-3).

Reynolds, C.M., P. Bhunia, and B.A. Koenen. 1997. Soil remediation demonstration project: biodegredation of heavy fuel oils. Hanover, NH: Cold Regions Research and Engineering Laboratory (CRREL special report 97. 20).

Sheppard, D.S., I.B. Campbell, G.G.C. Claridge, and J.M. Deely. 1994. Contamination of soils about Vanda Station, Antarctica. Lower Hutt, New Zealand: Institute of Geological and Nuclear Sciences (Science report 94/ 20).

Sheppard, D.S., G.G.C. Claridge, and I.B. Campbell. 2000. Metal contamination of soils at Scott Base, Antarctica. Applied Geochemistry 15: 513-530.

Smith, L.R.I. 1986. Plant ecological studies in the fellfield ecosystem near Casey station, Australian Antarctic Territory, 1985-86. British Antarctic Survey Bulletin 72: 81-91.

Smith, S.D.A., and R.D. Simpson. 1995. Effects of the 'Nella Dan' oil spill on the fauna of Durvillaea antarctica holdiasts. Marine Ecology Progress Series 121:73-89.

Snape, I., C.M. Cole, D.B. Gore, M.J. Riddle, and M. Yarnall. 1998. A preliminary assessment of contaminants at the abandoned Wilkes Station, East Antarctica, with recommendations for establishing an environmental management strategy. Kingston, Tasmania: Australian Antarctic Division.

Snape, I., S.H. Ferguson, P.D. Franzmann, C.E. Morris, and A.T. Revill. 2000. Contaminants in the Antarctic environment VIII: remediation of petroleum hydrocarbons. In: Hughson, T., and C. Ruckstuhl (editors). ISCORD 2000: Proceedings of the sixth international symposium on cold region development. Hobart: International Association of Cold Regions Development Studies: 148-150.

Snape, I., D.B. Gore, C.M. Cole, and M.J. Riddle. In press. Contaminant dispersal and mitigation at Casey Station: an example of how applied geoscience research can reduce environmental risks in Antarctica. Antarctic Earth Evolution and Process.

Snape, I., C.E. Morris, and C.M. Cole. In press. The use of permeable reactive barriers to control contaminant dispersal during site clean-up or remediation in Antarctica. Cold Regions Science and Technology.

Stark, J.S. 1998. Heavy metal pollution and macrobenthic assemblages in soft-sediments in two Sydney estuaries, Australia. Journal of Marine and Freshwater Research 49: 533-540.

Stark, J.S. 2000. The distribution and abundance of softsediment macrobenthos around Casey Station, East Antarctica. Polar Biology 23: 840-850.

Stark, J.S. 2001. Human impacts in nearshore, marine softsediment assemblages at Casey Station, Antarctica. Unpublished PhD thesis. Armidale, NSW: University of New England.

Underwood, A.J., and C.H. Peterson. 1988. Towards an ecological framework for investigating pollution. Marine Ecology Progress Series 129: 301-305. 